\title{
Applications of Biotechnology in Food and Agriculture: a Mini- Review
}

\author{
Muhammad Modassar Ali Nawaz Ranjha ${ }^{1}$ (D) Bakhtawar Shafique ${ }^{1}$. \\ Waseem Khalid ${ }^{2} \cdot$ Hafiz Rehan Nadeem ${ }^{3}$ - Ghulam Mueen-ud-Din ${ }^{1}$. \\ Muhammad Zubair Khalid ${ }^{2}$
}

Received: 27 October 2020/Revised: 9 October 2021 / Accepted: 10 November 2021/Published online: 11 January 2022

(C) The National Academy of Sciences, India 2022

\begin{abstract}
Biotechnology is a wide-ranging science that uses modern technologies to construct biological processes, organisms, cells or cellular components. The clinical new instruments, industry, and products developed by biotechnologists are useful in research, agriculture and other major fields. The biotechnology is as ancient as civilization. The food you buy, and the pets you love? Using artificial selection for crops, domesticated animals and other species, you may thank our distant ancestors for setting off the agrarian revolution. When Alexander Fleming discovered antibiotics, and when Edward Jenner invented vaccines, the biotechnology potential was harnessed. And, of course, without the mechanisms of fermentation that gave us beer, wine and cheese, it would not be possible to imagine modern society. This article summarizes some of the applications of biotechnology in food \& agriculture.
\end{abstract}

Biotechnology is a wide-ranging science that uses modern technologies to construct biological processes, organisms, cells or cellular components. This article summarizes some of the social implications of biotechnology.

Muhammad Modassar Ali Nawaz Ranjha

ModassarRanjha@gmail.com

1 Institute of Food Science and Nutrition, University of Sargodha, Sargodha, Pakistan

2 Institute of Home and Food Sciences, Government College University Faisalabad, Faisalabad, Pakistan

3 Institute of Food Science and Nutrition, Bahauddin Zakariya University, Multan, Pakistan
Graphical abstract Applications of biotechnology in animal and plant sector

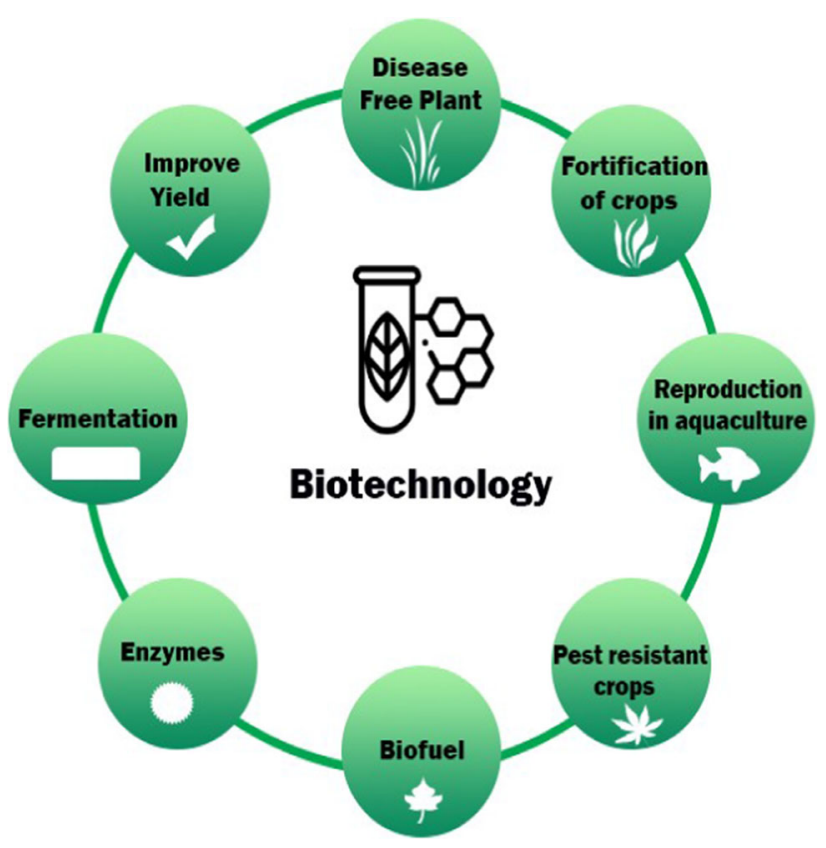

Keywords Biotechnology · Advancements · Applications . Food · Agriculture

\section{Introduction}

Products from natural sources are being used from centuries [1-3]. Processing the natural products to get significant benefits have been the priority in every era of science 
[4-7]. Biotechnology is an advanced, yet developed, technology that develops or modifies a product for some applied purpose utilizing living organisms and/or substances from these. It can be extended to all organism genera, i.e., from less complicated genera like viruses and bacteria to more complicated genera like plants and animals. So, biotechnology has become a major feature of modern industry, agriculture and medicine. Modern biotechnology provides a number of methods that scientists use to recognize and control the genetic structure of species for use in agricultural product development or processing [8].

The implications of biotechnology includes, breeding of plants for raising and stabilizing yields by improving their ability to confront various pests, insects and other possible threats, to fight various conditions like drought and counter diseases that could attack and cold and soil acidity, biotechnology is also being applied for nutritional enhancement of various foods $[9,10]$.

\section{Disease-Free Plants}

Disease-free plants are a very practical applications of biotechnology, these could be produced by micropropagation method. One of the examples of such plants is banana. Bananas are typically grown in countries where they emerge to be major source of income/employment and/or food. Micropropagation is a way to regenerate disease-free plantlets of bananas from tissues of healthy banana plants. It has all the possible benefits of being a revolutionary technique that is relatively inexpensive and easy to use [11].

\section{Agriculture on acid soils}

Lime can be applied to the soil to preserve the $\mathrm{pH}$ of the soil. This process emerges to be excellent but is expensive and temporary as well. Alternatively, it is possible to grow improved cultivars which are tolerant of aluminum [9].

\section{Fortification of Crops}

In developing countries or countries where there is a lot of shortage of food, fortified crops emerge to be an excellent food source which are supplemented with nutrients for rising malnourished children. One of the examples of such fortified crops is 'Protato'. This, genetically modified potato, is being widely cultivated and used in India and provides approximately one-third to one-half more protein than a common potato. In addition, this genetically modified potato also contains significant quantities of all essential amino acids, such as lysine and methionine. This 'Protato' could be a very potential food source in countries where potato is a major staple food [12]. Another example of such crops is golden rice. These genetically modified rice has a higher content of beta-carotene [13]. The grains and leaves of cowpeas are considered to be used as side or relish dishes. The cowpea is being consumed as staple food in various countries. The varieties of cowpeas with genetically modification has been grown in Tanzania [14]. The fortification of nutrients to enhance the nutritional status of crops, developed by genetically modified organisms with the major difference has been reported in Table1.

\section{Animal Feed}

Genetically modified crops are practically being used in developed countries. Such kind of crops have a very significant potential to provide more nutrients than the normal [22].

\section{Reproduction in Aquaculture}

Biotechnology has emerged to have great practical applications in aquaculture, biotechnology has helped to maximize the growth and production in the aquaculture. Research is being continued in this field for better and harmless production of aquatic organisms suitable for human consumption [23].

\section{Pest Resistant Crops}

Pest attack is one of the very common problem in a number of different crops all around the globe, these crops may include fodder crops or other crops for the purpose of getting food. One the example of such crops is BT-Cotton. The genes of Bacillus thuringiensis (Bt), a very common, are inserted in cotton crop in order for development of certain protein in it. The protein is very toxic to a number of different insects. With this aid of biotechnology, the developed BT-Cotton leads to a less pest attack ultimately leading to a significant more production [24].

\section{Drought Resistant Crops}

Targeted and short gun methods are two different two different but main techniques in genetic engineering. These techniques are applied in order to obtain transgenic plants that will possess the ability to confer drought resistance [10].

\section{Biofuel}

The prosperity of future is mainly based on the supply of equitable, secure, sustainable and affordable energy. Production of biofuel is one of the emerged trends in recent 
Table 1 The GM crops with major nutritional difference from original crops breeding

\begin{tabular}{|c|c|c|}
\hline $\begin{array}{l}\text { GM } \\
\text { Crops }\end{array}$ & Major difference & References \\
\hline Rice & $\begin{array}{l}\text { Naturally, the concentration of } \mathrm{Fe} \text { and } \mathrm{Zn} \text { in rice is low. The fortification causes enhancement in the iron and zinc } \\
\text { concentration }\end{array}$ & [15] \\
\hline Maize & $\begin{array}{l}\text { Production of varieties of maize with enhanced pro-vitamin A and carotenoids concentration, minerals concentration is } \\
\text { high in GM maize varieties, the biofortification of maize with } \beta \text {-carotenes has been reported }\end{array}$ & [16] \\
\hline Wheat & $\begin{array}{l}\text { Limited quantity of zinc and iron in wheat leads to the production of GM varieties with } 40-50 \% \text { greater concentration of } \\
\mathrm{Fe} \text { and } \mathrm{Zn}\end{array}$ & [17] \\
\hline Cassava & $\begin{array}{l}\text { Cassava is biofortified with } \beta \text {-carotene to improve the concentration of carotenes plus the iron and zinc quantity could be } \\
\text { enhanced with the addition of these minerals }\end{array}$ & [18] \\
\hline $\begin{array}{l}\text { Golden } \\
\text { rice }\end{array}$ & $\begin{array}{l}\text { Deficiency of vitamin A could be combated with the consumption of golden rice, as the concentration of } \beta \text {-carotene such } \\
\text { as pro-vitamin A is maximum in golden rice }\end{array}$ & [19] \\
\hline Bt rice & $\begin{array}{l}\text { Bt rice shows resistance toward bacterial and viral and fungal diseases. The attack of pest could be minimized as Bt rice } \\
\text { is considered as the novel ingredient to reduce the application of pesticides and regarded as friendly to aquatic life }\end{array}$ & {$[20]$} \\
\hline Bt maize & $\begin{array}{l}\text { Bt maize shows great resistance toward the corn borer. The development of transgenic varieties can minimize the attack } \\
\text { of various pest diseases }\end{array}$ & {$[21]$} \\
\hline Cowpea & Minerals such as calcium, iron and zinc content are higher in cowpea. The content of fat has been increased & [14] \\
\hline
\end{tabular}

$\mathrm{Bt}=$ Transgenic Bacillus thuringiensis

years. Biofuel could be an emerged and reliable substitute of fossil fuels. Six microalgae's strains were photosynthetically produced in a photobioreactor. Among these six microalgae, the Chlorella vulgaris strain is most dominant for the production of biodiesel. The Chlorella vulgaris has been used as feedstock. The quality of biofuel and productivity of lipids could be measured as a criterion for the selection of species to produce biodiesel [25].

\section{Vaccine Development}

Biotechnology has developed potential platform for scientists to develop wide ranges of vaccine in cheap and reliable ways and in mass production for all scales [26].

\section{Fermentation}

Fermentation is a predominant process to synthesize breweries. At commercial level, several strains of yeast are being utilized for the production of breweries. The light wine can be made through the mechanism of genetic engineering. Foreign gene encoded with glucoamylase has enabled to modify yeast. The glucoamylase is expressed through yeast during the fermentation process by which conversion of starch into glucose has been reported [27]. The strains of yeast are used for synthesis of wine which are capable of initiating malolactic fermentation. Synthesis of wine is comprised of two steps: 1) Primary fermentation uses yeast to convert the glucose into alcohol. 2) Secondary fermentation results in the production of lactic acid with the maximum acidity level using bacteria. The costly divergent strategies are applied to overcome this issue. The malolactic gene such as Lactobacillus delbrueckii is inserted into the strain of industrial yeast to resolve this problem. This gene depresses the conversion of malate hence minimizing the wine acidity level [27].

\section{Enzymes}

Enzymes are specifically used in processing and production of different items of food at industrial level. In 20th century second last decade, companies are being using enzymes to process food. The production of food is done by developing the technique of producing organisms through genetically modification. These enzymes contain carbohydrases and proteases. The maximum production could be achieved by the cloning of genes for these in minimum time period. These enzymes are specifically used for producing curd, cheese and flavoring items of food. Maximum percentage of enzymes are used in the industry of food. The more than $50 \%$ quantities of carbohydrases and proteases are being utilized in the USA industry of food. These enzymes comprise of $\alpha$-amylase and rennin [27].

\section{Use of Biotechnology to Improve Yield}

Milk is being consumed all over the world as a beneficial food with high nutritional value. The pituitary gland releases bovine Somatotropin hormone which increases the production of milk. Formerly, the calves were being slaughtered to extract this hormone from their brain. Nevertheless, that method results in the less hormone 
quantity. Scientists utilized Escherichia coli for the insertion of gene with encoded bovine Somatotropin in it. Now, this hormone results in the production of more quantity. This hormone obtains $10-12 \%$ increase in the production of milk. In 2050, the world's population will be reported nine billion. Consequently, on the same land, higher yield will be required. Potentially, biotechnology is the best technology to combat various food yield problem [27]. The greater level of hunger and poverty is reported in Africa. The malnutrition and hunger causes consequences in the case of in diseases such as rickets and kwashiorkor. These diseases result higher deaths. Africa can get rid of starvation, diseases, malnutrition and hunger with maximumly potential usage of biotechnology. It can improve standard of health and decrease rate of mortality. Three countries of Africa: Egypt, South Africa and Burkina Faso have been already profited through biotechnological adaptation of numerous methods of cultivation. For instance, 0.1 million Burkina Faso's farmers elevated the cotton yield by $126 \%$ with the potential use of GM technology of food. The technology of GM food is adopted which is required for the commercial system. It causes the products of GMO release, allergenicity tests, toxicity and digestivity of GM food. In that particular area, European Union and USA should assist Africa. Many countries of Africa deficient in the system of biosafety. African should develop biosafety laws and make sure their approval their as priority for the easily adoption of system. The deficiency of education is another obstacle in the technology of GM food's adoption. Kenyan people are much concerned about technology of GM food as they made protest against it. The lack of education is the major factor of the adverse attitude of people of Kenya toward biotechnology of food. People should be aware of advantages and disadvantages of GM technology of food through conveyance of message in seminars by scientists [28].

\section{Shell Life}

Various juice of fruits possesses minimum shell life. For instance, tomato is being consumed all over the world. Tomatoes should be harvested at stage of mature green in order to transportation. They are exposed to ethylene for earlier ripening and then picking. The quick ripening of tomatoes is due to more temperatures although, their taste could be destroyed at low temperature. A company of California named Calgene engineered genetically tomato to resolve that problem. They produced Flavr Savr variety of tomatoes in order to sort out the issue. An enzyme which is named as polygalacturonase causes the breakdown of pectin to ensure ripening. Scientists modified genetically tomatoes to decrease the quantity of enzyme. Antisense RNA is used for that specific purpose [28]. Low quantity of that enzyme shows consequences in the case of breakdown of cell wall and pectin in stronger tomatoes. These Flavr Savr variety possess tomatoes of firmer quality with increased shell life and later support transport [29].

\section{Biotechnology: Enhancing Taste}

Scientists are using the method of biotechnology for the production of fruits with enhanced taste. GM foods with enhanced taste are comprise of eggplant, cherries, pepper, seedless watermelon and tomato etc. The seed are removed from these fruits which shows better consequences such as more content of sugar with soluble form increasing sweetness in fruits [30]. The pathways of fermentation are altered by utilizing biotechnology for the purpose to add flavor and aroma in wine [27].

\section{Future Prospects}

There is requirement of research work to disprove or prove the local scientists' claims against GM food consumption. The layman should be questioned about potential dangers executed by GM food against human health and ecosystem, limited scientists can give response. Why is so?? Major reason is the lack of research associated to these areas. Consequently, GM food could be commercialized with the supreme confidence of scientists should to support food of GM technology and with making people argument about it.

\section{Conclusion}

The practical applications of biotechnology have merged to have helpful and safe production of sustained food. More research is recommended in the said field for better and safe production and processing technologies and techniques.

Acknowledgements The authors have no acknowledgements to endorse.

\section{Declarations}

Conflict of interests The authors declare that they have no conflicts of interests.

\section{References}

1. Ranjha MMAN, Irfan S, Nadeem M, Mahmood S (2020) A comprehensive review on nutritional value, medicinal uses, and processing of banana. Food Rev Int. https://doi.org/10.108 0/87559129.2020.1725890

2. Ranjha MMAN, Amjad S, Ashraf S et al (2020) Extraction of polyphenols from apple and pomegranate peels employing different extraction techniques for the development of functional 
date bars. Int $\mathbf{J}$ Fruit Sci. https://doi.org/10.1080/1 5538362.2020.1782804

3. Ranjha MMAN, Shafique B, Wang L et al (2021) A comprehensive review on phytochemistry, bioactivity and medicinal value of bioactive compounds of pomegranate (Punica granatum). Adv Tradit Med. https://doi.org/10.1007/s1359 6-021-00566-7

4. Nadeem HR, Akhtar S, Ismail T et al (2021) Heterocyclic aromatic amines in meat: formation, isolation, risk assessment, and inhibitory effect of plant extracts. Foods 10:1466. https://doi.org/ 10.3390/foods 10071466

5. Ranjha MMAN, Kanwal R, Shafique B, et al (2021) A critical review on pulsed electric field: a novel technology for the extraction of phytoconstituents. Molecules 26:4893. https://doi.org/10.3390/molecules26164893

6. Ranjha MMAN, Irfan S, Lorenzo JM et al (2021) Sonication, a potential technique for extraction of phytoconstituents: a systematic review. Processes 9:1406. https://doi.org/10.3390/pr9 081406

7. Nadeem M, Ghaffar A, Hashim MM et al (2021) Sonication and microwave processing of phalsa drink: a synergistic approach. Int J Fruit Sci 21:993-1007. https://doi.org/10.1080/155383 62.2021 .1965942

8. Khan MI, Rashid B, Tariq M et al (2017) Crop improvement: new approaches and modern techniques. Plant Gene Trait. https://doi.org/10.5376/pgt.2017.08.0003

9. Kole C (2012) Wild crop relatives: Genomic and breeding resources: Cereals. Springer Science \& Business Media.

10. Khan S, Khan J (2010) Drought tolerant wheat cultivar (raj) for rainfed areas of Kpk, Pakistan. Pakistan J Agric Sci 47:355-359

11. Jain A, Singh N, Kumari S, Khan S (2021) Bioentrepreneurship in agricultural biotechnology. In: Agarwal S, Kumari S, Khan S (eds) Bioentrepreneurship and Transferring Technology Into Product Development. IGI Global, Hershey, PA, USA, pp 183-200

12. Rajasree V, Pugalendhi L (2021) Breeding Vegetables for Nutritional Security. In: Jovandaric LPE-MZ (ed) Veganism-a Fashion Trend or Food as a Medicine. IntechOpen, Rijeka, p Ch. 7

13. Qamar S, Tantray AY, Bashir SS, et al (2020) Golden rice: genetic engineering, promises, present status and future prospects. In: A. R (ed) Rice Research for Quality Improvement: Genomics and Genetic Engineering. Springer, Singapore, pp 581-604

14. Mamiro P, Mbwaga A, Mamiro D et al (2011) Nutritional quality and utilization of local and improved cowpea varieties in some regions in tanzania. African $\mathrm{J}$ Food Agric Nutr Dev 11:4490-4506

15. Brinch-Pedersen H, Borg S, Tauris B, Holm PB (2007) Molecular genetic approaches to increasing mineral availability and vitamin content of cereals. J Cereal Sci 46:308-326. https://doi.org/ 10.1016/j.jcs.2007.02.004

16. Hefferon KL (2015) Nutritionally Enhanced Food Crops; Progress and Perspectives. 3895-3914. https://doi.org/10.3390/ijms1 6023895
17. Mulualem T (2015) Application of bio-fortification through plant breeding to improve the value of staple crops. Biomed Biotechnol 3:11-19. https://doi.org/10.12691/bb-3-1-3

18. Montagnac JA, Davis CR, Tanumihardjo SA (2009) Nutritional value of cassava for use as a staple food and recent advances for improvement. Compr Rev Food Sci Food Saf 8:181-194. https://doi.org/10.1111/j.1541-4337.2009.00077.x

19. Paine JA, Shipton CA, Chaggar S et al (2005) Improving the nutritional value of golden rice through increased pro-vitamin a content. Nat Biotechnol 23:482-487. https://doi.org/10.1038/n bt1082

20. Li G, Wang Y, Liu B, Zhang G (2014) Transgenic Bacillus thuringiensis $(\mathrm{Bt})$ rice is safer to aquatic ecosystems than its nontransgenic counterpart. PLoS ONE. https://doi.org/10.1371/jo urnal.pone. 0104270

21. Traore SB, Carlson RE, Pilcher CD, Rice ME (2000) Bt and non$\mathrm{Bt}$ maize growth and development as affected by temperature and drought stress. Agron J 92:1027-1035. https://doi.org/10.2134/ agronj2000.9251027x

22. Kumar K, Gambhir G, Dass A et al (2020) Genetically modified crops: current status and future prospects. Planta 251:91. https://doi.org/10.1007/s00425-020-03372-8

23. Jin YH, Robledo D, Hickey JM et al (2021) Surrogate broodstock to enhance biotechnology research and applications in aquaculture. Biotechnol Adv 49:107756. https://doi.org/10.1016/j.biot echadv.2021.107756

24. Qaim M (2020) Bt cotton, yields and farmers' benefits. Nat Plants 6:1318-1319. https://doi.org/10.1038/s41477-020-00788-8

25. Francisco ÉC, Neves DB, Jacob-Lopes E, Franco TT (2010) Microalgae as feedstock for biodiesel production: carbon dioxide sequestration, lipid production and biofuel quality. J Chem Technol Biotechnol 85:395-403. https://doi.org/10.1002/ jctb. 2338

26. de Sá MS, Keshavarz-Moore E (2021) Pichia pastoris (Komagataella phaffii) as a cost-effective tool for vaccine production for low- and middle-income countries (LMICs). Bioeng 8:119

27. Haroon F, Ghazanfar M (2016) Applications of food biotechnology. J Ecosyst Ecography. https://doi.org/10.4172/215 7-7625.1000215

28. Adenle AA (2011) Response to issues on GM agriculture in Africa: are transgenic crops safe? BMC Res Notes 4:2-7. https://doi.org/10.1186/1756-0500-4-388

29. F. S, Dawkins B (2010) A Study Of The Production, Marketing, And Consumption Of Citrus Fruits Approved t Approved: Dean of Division of Graduate Studies

30. Falk MC, Chassy BM, Harlander SK et al (2002) Food biotechnology: benefits and concerns. J Nutr 132:1384-1390. https://doi.org/10.1093/jn/132.6.1384

Publisher's Note Springer Nature remains neutral with regard to jurisdictional claims in published maps and institutional affiliations. 